\title{
Trace Elements Concentration in Surface Water Used for Irrigation in Kosovo
}

\author{
Smajl Rizani, Perparim Laze* \\ Department of Plant Science and Technology, Agricultural University of Tirana (AUT), Albania
}

Copyright $\subset 2017$ by authors, all rights reserved. Authors agree that this article remains permanently open access under the terms of the Creative Commons Attribution License 4.0 International License

\begin{abstract}
The aim of this study is to assess the quality of the surface water used for irrigation purposes by examining the presence of trace elements in the main irrigation sources in Kosovo. Samples were taken from several of these sources (rivers, some reservoirs, pump stations and canals) and were then analyzed for trace elements content such as zinc, iron, copper, manganese, lead, nickel, cobalt, cadmium, chromium, and molybdenum, by Microwave Plasma Atomic Emission Spectrometry (MP-AES 4100). The findings revealed no significant differences in terms of trace elements content in the samples coming from the various sources. Copper, manganese, nickel, cobalt, lead and chromium were found in normal concentrations in all the water sources, whereas zinc and iron were found to be in deficient concentrations. Cadmium was at recommended maximum concentrations. Molybdenum is found in high concentrations especially in the water samples taken from pump stations and irrigation reservoirs. In the future it is necessary to closely and continuously monitor the concentrations of molybdenum in the irrigation waters of this area. Furthermore, it is essential to identify the causes of the high molybdenum levels in these waters. However, these sources can be used for irrigation purposes without posing a threat to the soil and plants.
\end{abstract}

Keywords Trace Elements, Concentration, Toxic, Irrigation Water, Water Sources, Kosovo

\section{Introduction}

Trace elements are natural constituents of the soils or the underlying geologic materials and may be mobilized by irrigation [20]. Assessing the quality of the irrigation water, in terms of trace elements presence in water is very important because it may transport dissolved heavy metals to agricultural fields [26]. The term "heavy metals" is commonly used to refer to elements with metallic properties [6]. They have a relatively high density compared to water [4]; [12]. Another description often used interchangeably with heavy metals is "trace elements" [15]; [21]. They are also considered as such because of their presence in trace concentrations in various environmental matrices [15].

Trace elements occur in almost all water supplies but at very low concentrations [5]. While some of these elements, otherwise known as micronutrients, have essential functions in plant cells, once the internal concentration exceeds a certain threshold they have been shown to exert toxic effects. The discharge of industrial and municipal waste without the necessary prior treatment introduces heavy metals pollution into water bodies [14]. The contamination caused by the heavy metals and organic pollutants is virtually irreversible; therefore, making this issue one of the most alarming. Contamination can affect human health either through direct contact or by ingestion through the food chain [10].

Researchers suggest that farmers should use clean water for irrigation in order to reduce the levels of heavy metals entering the food chain, because certain vegetables take up heavy metals from contaminated water used for irrigation [24].

The problem of heavy metals entering the food chain requires systematic assessments to make timely decisions to avoid severe health effects because of the invisible mode of heavy metal toxicity [7].

There is no previous comprehensive research concerning the status of water used in the irrigation of agricultural crops considering trace elements in Kosovo. Therefore, the assessment of water used for irrigation from surface water sources for the presence of trace elements is of great importance. This study assesses the quality of the irrigation water in terms of trace elements presence in surface water for several irrigation sources: rivers, some reservoirs, pump stations and canals.

\section{Material and Methods}

\subsection{Study Area}

The study was conducted in the territory of Kosovo. Kosovo is located between the Mediterranean Sea and mountainous regions of Southeast Europe, on the Balkan 
Peninsula. The territory extends within the latitude $41^{\circ} 50^{\prime}$ $58^{\prime \prime}$ and $43^{\circ} 15^{\prime} 42^{\prime \prime}$ and within the longitude $20^{\circ} 01^{\prime} 30^{\prime \prime}$ and $21^{\circ} 48^{\prime} 02^{\prime \prime}$. This geographic location gives the country its wide annual temperature range. Summer temperature highs can reach $+30{ }^{\circ} \mathrm{C}$, whereas temperatures in the winter are as low as $-10{ }^{\circ} \mathrm{C}$. The climate in Kosovo is considered moist continental. The country experiences warm summers and cold winters characterized by heavy snowfall. The average annual precipitation of this climatic area is about $700 \mathrm{~mm}$ per year. On the other hand, the mountainous and forested areas are characterised by a typical forest clime, which is associated with heavy rainfalls (900 to $1300 \mathrm{~mm}$ per year), and summers that are very short and cold, and winters that are cold and with a lot of snow. Finally, it can be stated that the Kosovo territory is characterised by a sunny climate with variable temperatures and humidity conditions.

In Kosovo there are many rivers flowing in the Adriatic Sea, the Black Sea and the Aegean Sea. The main rivers of Kosovo are: Drini i Bardhe, Ibair, Lepence, Sitnica, Morava e Bisnecës, Bistrica e Pejes and Bistrica e Deçanit, Istog River, Erenik, Prizren River, Toplluha, Mirusha, Klina, Plava River etc. Kosovo also has a large number of karstic springs, thermal and mineral springs, glacial valleys and natural and artificial lakes.

Four different sources of irrigation water were selected; Rivers (Drini i Bardhe, Sitnica, Bistrica e Decanit, Bistrica e Pejes, Istog and Erenik), Reservoirs, Pump stations and Canal irrigation water.

\subsection{Collection of Water Samples}

The sources from which the samples were taken, were selected in such a way that all the significant agricultural areas in Kosovo were included. After extensive research which included visiting the territory, investigating and gathering field data from the responsible authorities, it was established that all the selected sources were used for irrigation and thus fit the criteria of the study. Water samples were collected from 36 sampling points and their locations were recorded accurately with a GPS device (Figure 1). A total of 72 surface water samples were collected from sampling points in the cropping period of the peak dry season (July-August, 2015).

The samples taken were categorized as follows: 14 water samples were collected from the rivers, 16 from pump stations, 36 from canals and the rest from the reservoirs. Each sample was collected using a clean plastic bottle of a 10 $\mathrm{cm}$ depth. The bottles were kept air tight and labeled properly for identification. Aeration during sampling was avoided by stoppering the bottle quickly. Samples collected from the study areas were carefully transported to the laboratory and were preserved in a refrigerator for analysis. These water samples were analyzed for $\mathrm{pH}$ and trace elements content ( $\mathrm{Zn}, \mathrm{Fe}, \mathrm{Cu}, \mathrm{Mn}, \mathrm{Ni}, \mathrm{Co}, \mathrm{Pb}, \mathrm{Cr}, \mathrm{Cd}, \mathrm{Mo}$ ).

\subsection{Analytical Procedure}

Temperature and $\mathrm{pH}$ of the samples were measured on the spot using respectively, a thermometer and $\mathrm{pH}-$ meter. The analyses for heavy metals content $\mathrm{Zn}, \mathrm{Fe}, \mathrm{Cu}, \mathrm{Mn}, \mathrm{Ni}, \mathrm{Co}$, $\mathrm{Pb}, \mathrm{Cr}, \mathrm{Cd}, \mathrm{Mo}$ ) in the water samples were carried out by microwave plasma atomic emission spectrometry-MP-AES 4100 [27]. They were performed in the laboratory of the Agricultural Institute of Kosovo, Peje, between July and August 2015.

The trace elements concentration found in the water samples was compared with the 'Recommended maximum concentration' of irrigation water [11] and limit values presented in 75/440/EEC and 2008/105EC Directives [8-9].

\section{Results and Discussion}

Results from the analyzed samples of water sources (rivers, pump stations, canals and reservoirs) are shown in table 1. This table displays the mean values of $\mathrm{pH}$ and the mean values of trace elements content and recommended maximum concentration of trace elements in irrigation waters [11]; [8-9]. 


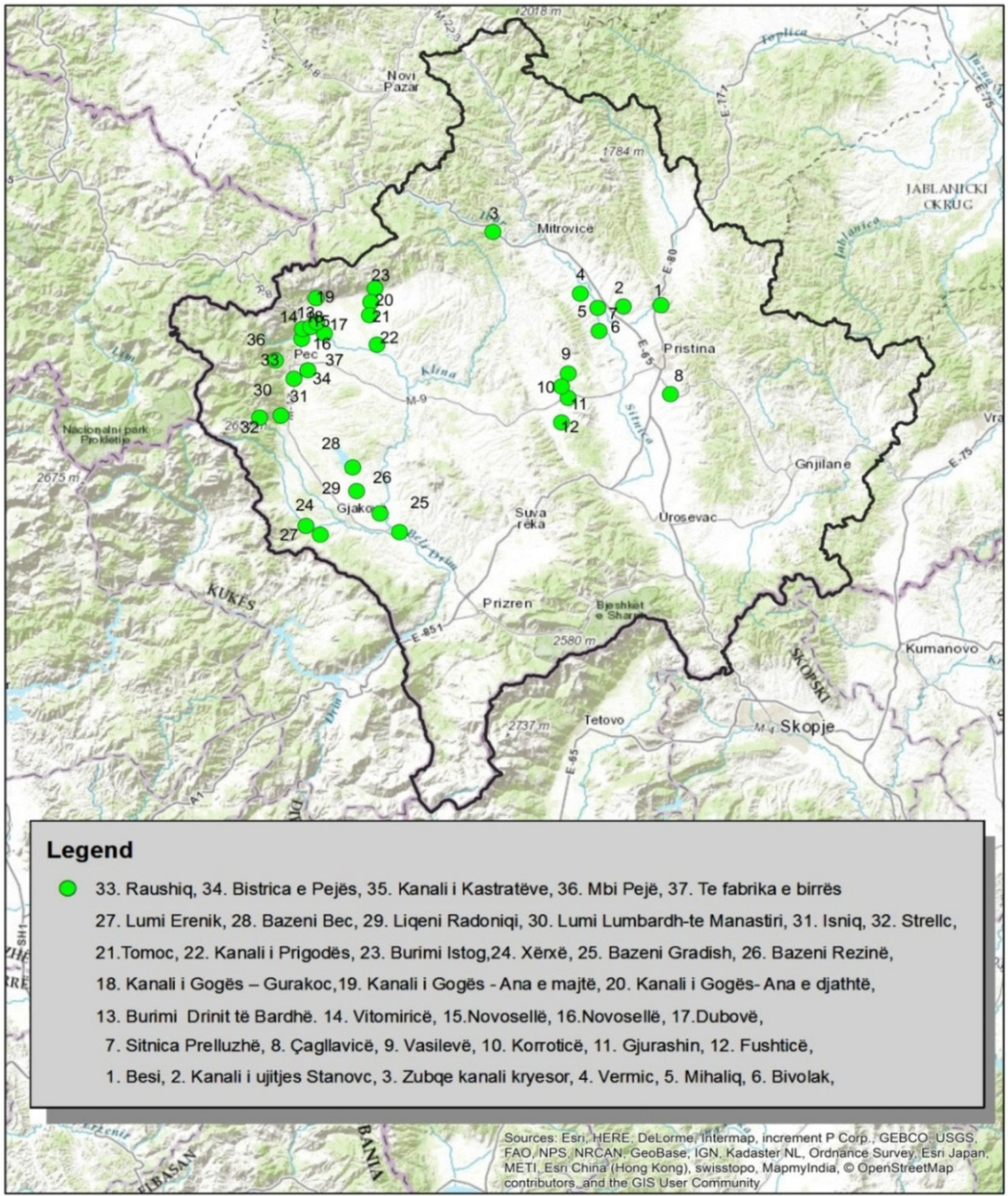

Figure 1. Sampling points of irrigation water sources 
Table 1. Average trace elements content of surface water used for irrigation

\begin{tabular}{|c|c|c|c|c|c|c|c|c|c|c|c|}
\hline $\begin{array}{l}\text { Irrigation water } \\
\text { sources, location } \\
\text { and number of } \\
\text { sampling point }\end{array}$ & $\mathrm{pH}$ & $\mathrm{Zn}$ & $\mathrm{Fe}$ & $\mathrm{Cu}$ & Mo & $\begin{array}{l}\mathrm{Mn} \\
\mathrm{mg} / 1\end{array}$ & $\mathrm{Ni}$ & Co & $\mathrm{Pb}$ & $\mathrm{Cr}$ & $\mathrm{Cd}$ \\
\hline \multicolumn{12}{|l|}{ I. RIVERS } \\
\hline Sitnica (7) & 7.50 & 0.06 & 0.02 & $*$ & $*$ & $<0.1$ & $*$ & $*$ & $*$ & $*$ & $*$ \\
\hline Bistrica Decan (13) & 6.83 & 0.08 & 0.01 & $*$ & $*$ & $<0.1$ & $*$ & $*$ & $*$ & $*$ & $*$ \\
\hline Bistrica Peje (17) & 7.46 & 0.08 & 0.01 & $*$ & $*$ & $<0.1$ & $*$ & $*$ & $*$ & $*$ & $*$ \\
\hline Bistrica Peje (20) & 7.39 & 0.08 & 0.02 & $*$ & $*$ & $<0.1$ & $*$ & $*$ & $*$ & $*$ & $*$ \\
\hline Drini i Bardhe (21) & 7.71 & 0.08 & 0.02 & $*$ & $*$ & $<0.1$ & $*$ & $*$ & $*$ & $*$ & $*$ \\
\hline Istog (31) & 7.69 & 0.08 & 0.02 & $*$ & $*$ & $<0.1$ & $*$ & $*$ & $*$ & $*$ & $*$ \\
\hline Erenik (35) & 7.67 & 0.08 & 0.02 & $*$ & $*$ & $<0.1$ & $*$ & $*$ & $*$ & $*$ & $*$ \\
\hline MEAN & 7.46 & 0.08 & 0.017 & $*$ & $*$ & $<0.1$ & $*$ & $*$ & $*$ & $*$ & $*$ \\
\hline \multicolumn{12}{|c|}{ II. PUMP STATIONS } \\
\hline Besi - MPS (1) & 7.68 & 0.07 & 0.01 & $*$ & 0.02 & $<0.1$ & $*$ & $*$ & $*$ & $*$ & $*$ \\
\hline Mihaliq-DO2 (5) & 7.69 & 0.07 & 0.01 & $*$ & 5.9 & $<0.1$ & $*$ & $*$ & $*$ & $*$ & $*$ \\
\hline Bivolak - MPS (6) & 7.71 & 0.06 & 0.02 & $*$ & 0.16 & $<0.1$ & $*$ & $*$ & $*$ & $*$ & $*$ \\
\hline Cagllavice - (8) & 7.63 & 0.06 & 0.03 & $*$ & $*$ & $<0.1$ & $*$ & $*$ & $*$ & $*$ & $*$ \\
\hline Vasiliev - (9) & 7.61 & 0.07 & 0.02 & $*$ & 0.79 & $<0.1$ & $*$ & $*$ & * & $*$ & $*$ \\
\hline Koratice-PSI-9 (10) & 7.60 & 0.06 & 0.01 & $*$ & 0.12 & $<0.1$ & $*$ & $*$ & $*$ & $*$ & $*$ \\
\hline Gjurashin-PSI-(11) & 7.60 & 0.07 & 0.02 & $*$ & 0.84 & $<0.1$ & $*$ & $*$ & $*$ & $*$ & $*$ \\
\hline Fushtice-PSI-7 (12) & 7.60 & 0.08 & 0.02 & $*$ & 0.13 & $<0.1$ & $*$ & $*$ & $*$ & $*$ & $*$ \\
\hline MEAN & 7.64 & 0.067 & 0.017 & $*$ & 1.00 & $<0.1$ & $*$ & $*$ & $*$ & $*$ & $*$ \\
\hline \multicolumn{12}{|l|}{ III. CANALS } \\
\hline Stanove (2) & 7.62 & 0.08 & 0.02 & $*$ & $*$ & $<0.1$ & $*$ & $*$ & $*$ & $*$ & $*$ \\
\hline Zubq (3) & 7.70 & 0.06 & 0.01 & $*$ & $*$ & $<0.1$ & $*$ & $*$ & $*$ & $*$ & $*$ \\
\hline Verbnice (4) & 7.65 & 0.07 & 0.02 & $*$ & $*$ & $<0.1$ & $*$ & $*$ & $*$ & $*$ & $*$ \\
\hline Isniq (14) & 6.98 & 0.08 & 0.02 & $*$ & $*$ & $<0.1$ & $*$ & $*$ & $*$ & $*$ & $*$ \\
\hline Strellc (15) & 7.19 & 0.08 & 0.01 & $*$ & $*$ & $<0.1$ & $*$ & $*$ & $*$ & $*$ & $*$ \\
\hline Rahushiq (16) & 7.35 & 0.07 & 0.02 & $*$ & $*$ & $<0.1$ & $*$ & $*$ & $*$ & $*$ & $*$ \\
\hline Loxhe (18) & 7.38 & 0.08 & 0.02 & $*$ & * & $<0.1$ & $*$ & $*$ & $*$ & $*$ & * \\
\hline Peje (19) & 7.30 & 0.09 & 0.01 & $*$ & $*$ & $<0.1$ & $*$ & $*$ & $*$ & $*$ & $*$ \\
\hline Vitomerice (22) & 7.46 & 0.08 & 0.01 & $*$ & $*$ & $<0.1$ & $*$ & $*$ & $*$ & $*$ & $*$ \\
\hline Novoselle (23) & 7.38 & 0.08 & 0.02 & $*$ & $*$ & $<0.1$ & $*$ & $*$ & $*$ & $*$ & $*$ \\
\hline Novoselle (24) & 7.47 & 0.07 & 0.01 & $*$ & $*$ & $<0.1$ & $*$ & $*$ & $*$ & $*$ & $*$ \\
\hline Dubove (25) & 7.50 & 0.08 & 0.02 & $*$ & $*$ & $<0.1$ & $*$ & $*$ & $*$ & $*$ & $*$ \\
\hline Gurakoc (26) & 7.41 & 0.08 & 0.01 & $*$ & $*$ & $<0.1$ & $*$ & $*$ & $*$ & $*$ & $*$ \\
\hline Kanali Gog.1 (27) & 7.69 & 0.08 & 0.02 & $*$ & * & $<0.1$ & $*$ & $*$ & $*$ & $*$ & * \\
\hline Kanali Gog. 2 (28) & 7.67 & 0.09 & 0.02 & $*$ & $*$ & $<0.1$ & $*$ & $*$ & $*$ & $*$ & $*$ \\
\hline Tomoc (29) & 7.46 & 0.08 & 0.01 & $*$ & $*$ & $<0.1$ & $*$ & $*$ & $*$ & $*$ & * \\
\hline Rudice, Kline (30) & 7.48 & 0.08 & 0.02 & $*$ & $*$ & $<0.1$ & $*$ & $*$ & $*$ & $*$ & $*$ \\
\hline Xerxe (32) & 7.50 & 0.08 & 0.02 & $*$ & $*$ & $<0.1$ & $*$ & $*$ & $*$ & $*$ & $*$ \\
\hline MEAN & 7.45 & 0.078 & 0.016 & $*$ & $*$ & $<0.1$ & $*$ & $*$ & $*$ & $*$ & $*$ \\
\hline \multicolumn{12}{|c|}{ IV. RESERVOIRS } \\
\hline Bazen Gradish (33) & 7.60 & 0.07 & 0.02 & $*$ & $*$ & $<0.1$ & $*$ & $*$ & * & $*$ & $*$ \\
\hline Bazen Rezine (34) & 7.67 & 0.07 & 0.02 & $*$ & 0.1 & $<0.1$ & $*$ & $*$ & $*$ & $*$ & * \\
\hline Bazen 10, Bec (36) & 7.57 & 0.08 & 0.01 & $*$ & 0.04 & $<0.1$ & $*$ & $*$ & * & & * \\
\hline
\end{tabular}




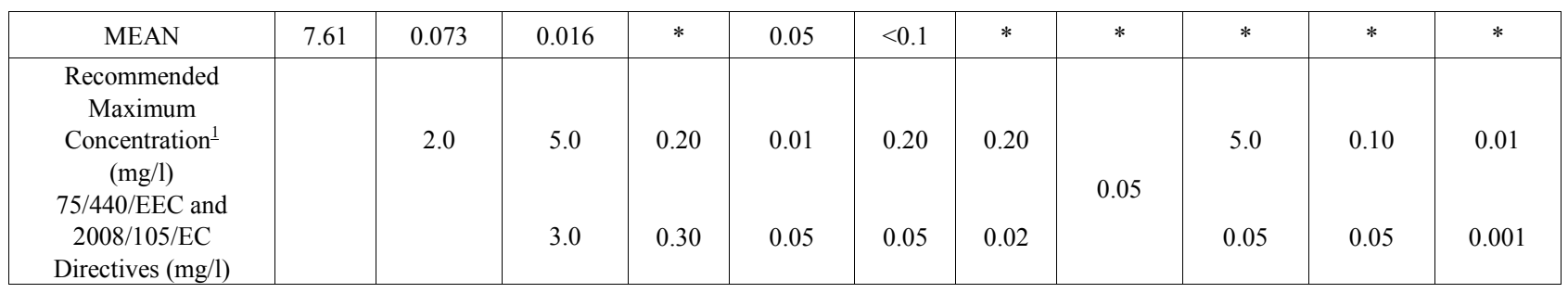

1Adapted from National Academy of Sciences (1972) and Pratt (1972). “** Trace elements concentration $<0.02 \mathrm{mg} / 1$

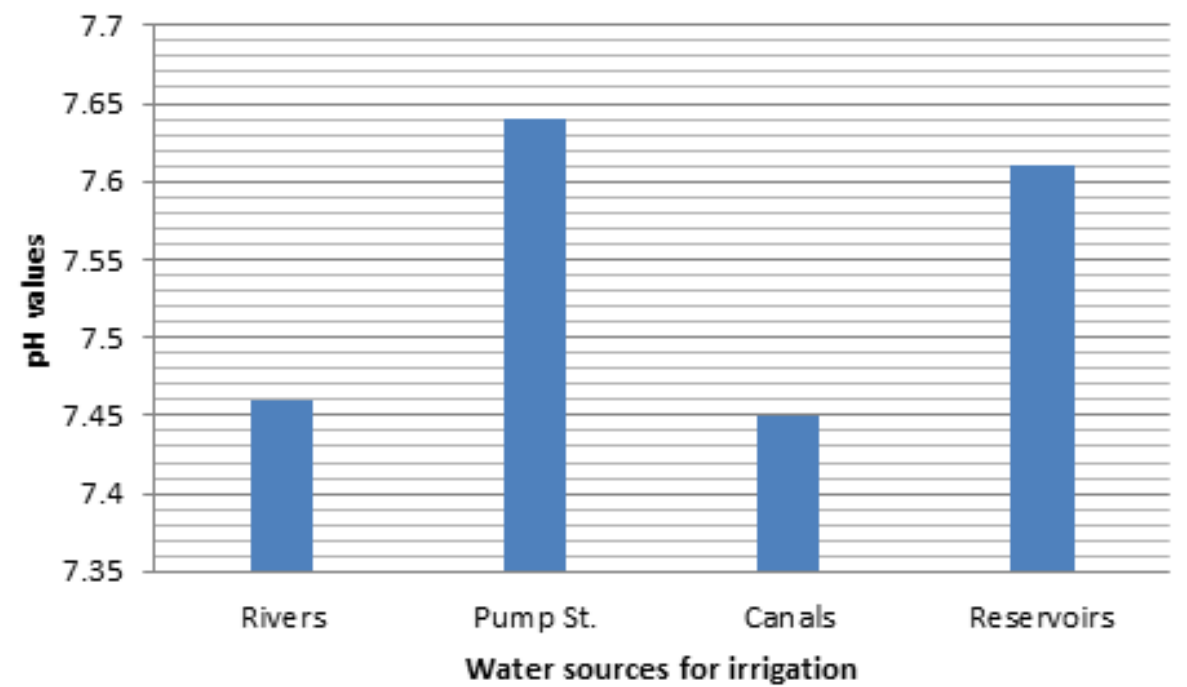

Figure 2. $\mathrm{pH}$ average values of water sources for irrigation

\section{1. pH Measurement}

The average $\mathrm{pH}$ values of the water samples in the all water sources used for irrigation ranged from 6.83 to 7.71 (Table 1), showing the alkaline nature of water. $\mathrm{pH}$ values in the water samples taken from the pump stations and reservoirs were slightly higher than those of the water samples collected from the rivers and canals (Figure 2). However there are no significant differences between the water sources (rivers, canals, pump stations and reservoirs) and these values are within permissible limits for irrigation water [5].

\subsection{Trace Elements}

As it is shown by the results of the analyses there is presence of trace elements in all the water samples from the water sources which are used for irrigation in Kosovo. Their values vary by the type of metal and by the water samples analyzed.

The concentration of trace elements in irrigation water samples taken from the rivers has resulted in this order: $\mathrm{Mn}>\mathrm{Zn}>\mathrm{Mo}>\mathrm{Fe}$ (Figure 3). All other elements were in concentrations lower than $0.02 \mathrm{mg} / \mathrm{l}$. Study findings indicate that the content of trace elements in irrigation water vary as follows: $\mathrm{Zn} 0.06-0.08 \mathrm{mg} / \mathrm{l}, \mathrm{Fe} 0.01-0.02 \mathrm{mg} / \mathrm{l}, \mathrm{Mn} \sim 0.1$ $\mathrm{mg} / \mathrm{l}$ and all other elements $<0.02 \mathrm{mg} / \mathrm{l}$ (Table 1 ).

Regarding the content of trace elements in the irrigation water supplied by the pumping stations, this ranking is shown $\mathrm{Mo}>\mathrm{Mn}>\mathrm{Zn}>\mathrm{Fe}$ (Figure 4). All other elements were in concentrations lower than $0.02 \mathrm{mg} / \mathrm{l}$. The data of the study demonstrates that the content of trace elements in irrigation water supplied from pump stations is as follows: $\mathrm{Zn} 0.06$ $0.08 \mathrm{mg} / \mathrm{l}, \mathrm{Fe} 0.01-0.03 \mathrm{mg} / \mathrm{l}, \mathrm{Mn} \sim 0.1 \mathrm{mg} / \mathrm{l}$ and Mo from $<0.02$ to $5.9 \mathrm{mg} / \mathrm{l}$ (Table 1$)$.

From the results of the analyses of the trace elements content in the canal irrigation water, we see that there are differences in their values between the sampling points for two elements, $\mathrm{Zn}(0.06-0.09 \mathrm{mg} / \mathrm{l})$ and $\mathrm{Fe}(0.01-0.02 \mathrm{mg} / \mathrm{l})$. The other elements are found in concentrations of less than $0.02 \mathrm{mg} / \mathrm{l}$ (Table 1). In the irrigation water coming from canals the concentration values of trace elements are found in the following order: $\mathrm{Mn}>\mathrm{Zn}>\mathrm{Mo}>\mathrm{Fe}$ (Figure 5).

In the irrigation water of reservoirs, the concentration of trace elements varies between the sampling points as follows: Zn $(0.07-0.08 \mathrm{mg} / \mathrm{l})$, Fe (0.01-0.0 $3 \mathrm{mg} / \mathrm{l})$, Mo $(<0.02-1.1$ $\mathrm{mg} / \mathrm{l}), \mathrm{Mn}<0.1 \mathrm{mg} / \mathrm{l}$. All the other elements found were found in concentrations $<0.02 \mathrm{mg} / \mathrm{l}$. Figure 6 makes is evident that the concentration values of the trace elements found in the water samples coming from irrigation reservoirs follow the same order as the ones found in the water samples coming from irrigation canals.

By analyzing the concentration of trace elements $\mathrm{Zn}, \mathrm{Fe}$ and Mo, which are represented by variables at sampling points and sources of irrigation water in Kosovo, we will have the following:

The average $\mathrm{Zn}$ content is relatively higher in river water samples, pumping stations and reservoirs compared to those of irrigation canals (Figure 7). 


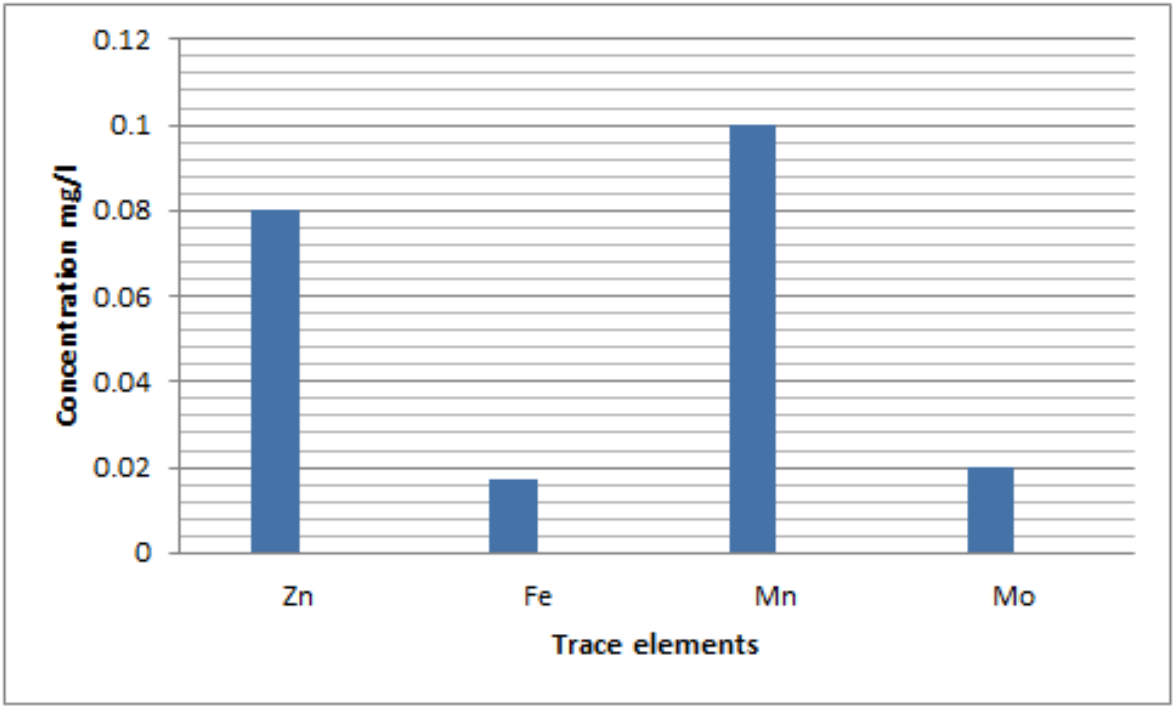

Figure 3. Trace elements concentration in water samples taken from rivers

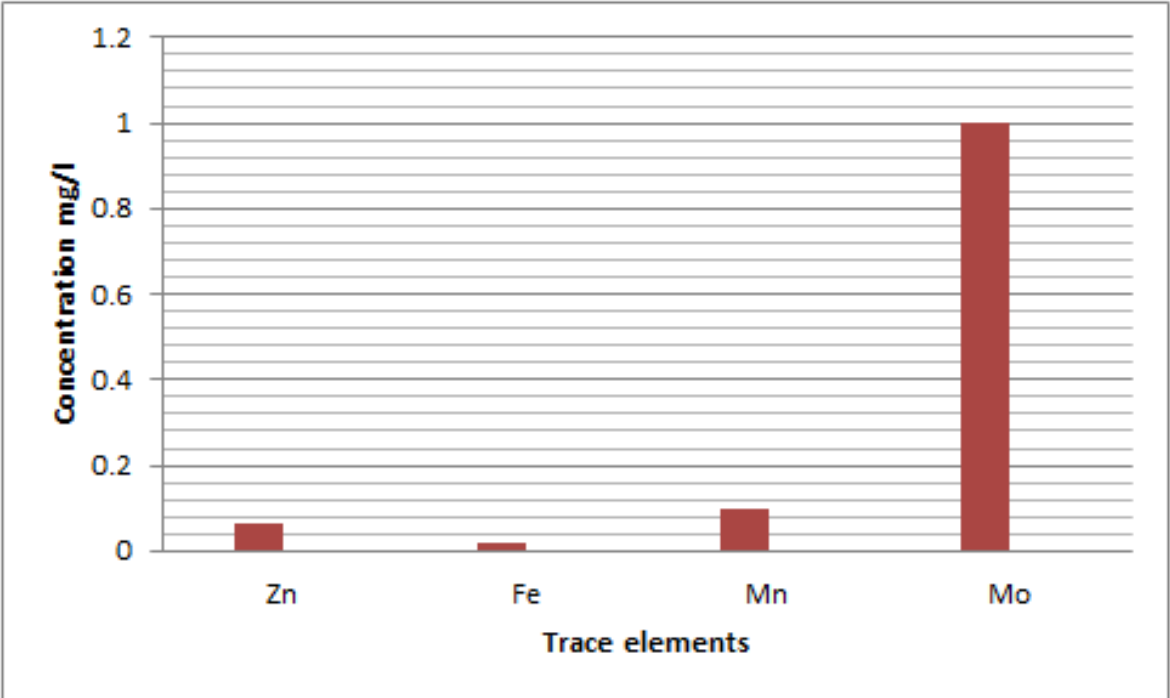

Figure 4. Trace elements concentration in water samples taken from Pump Stations

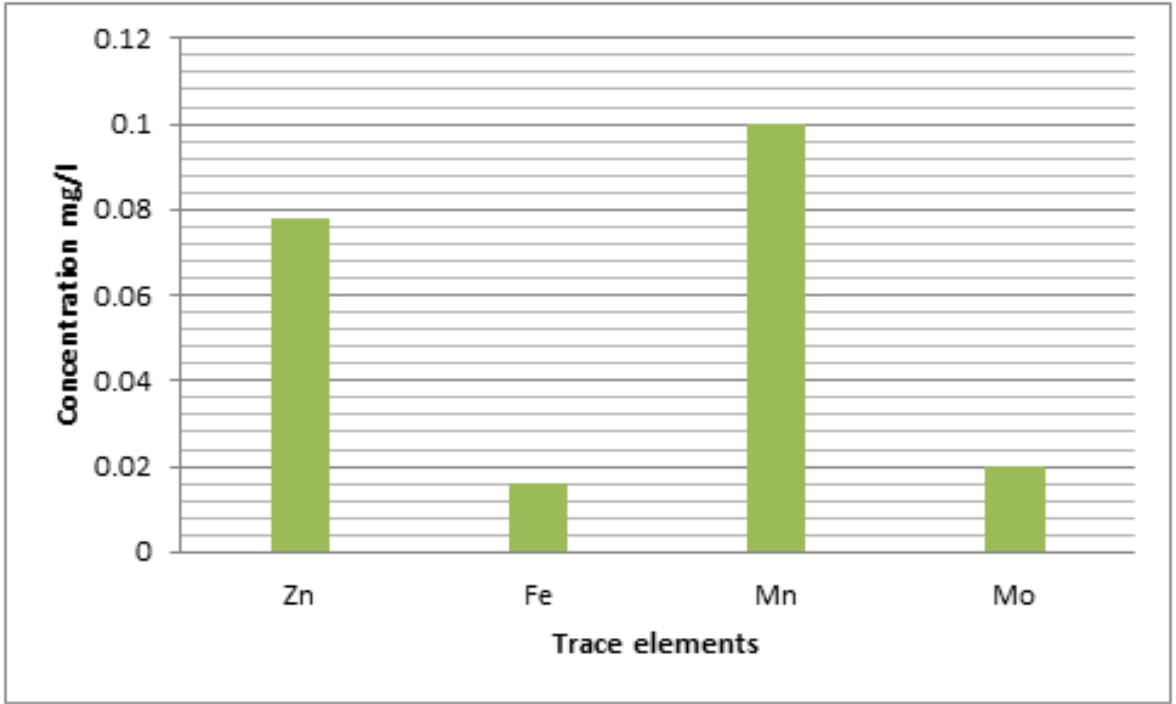

Figure 5. Trace elements concentration in water samples taken from irrigation canals 


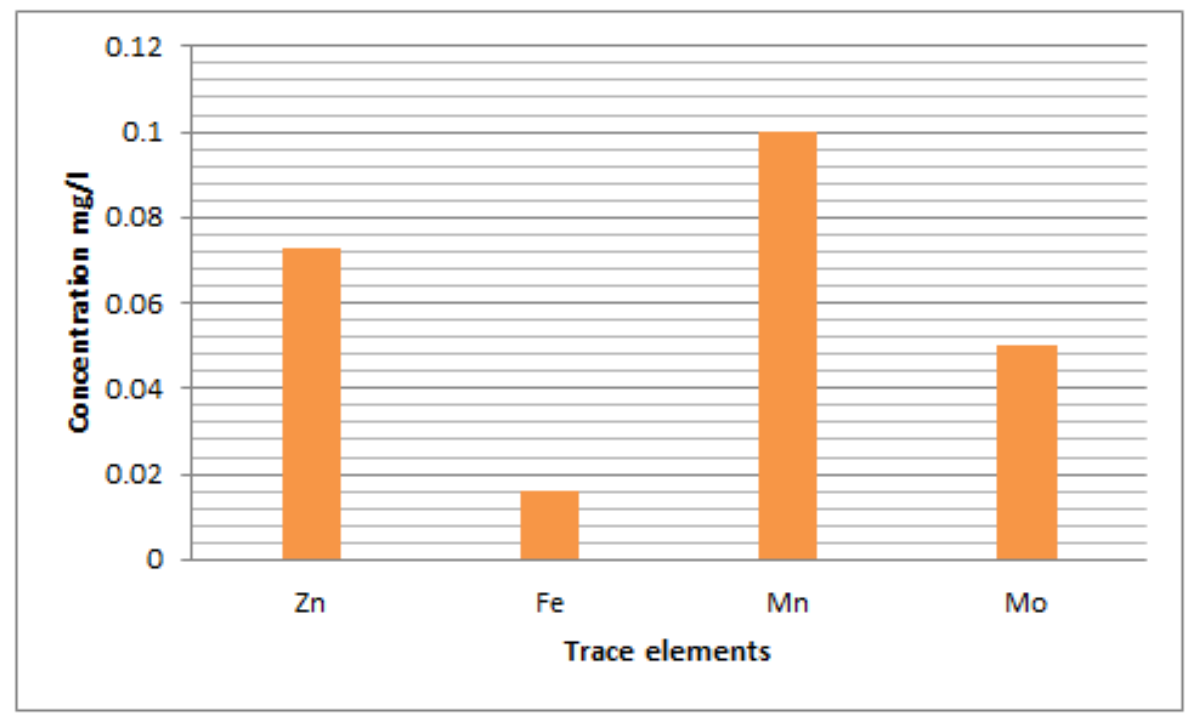

Figure 6. Trace elements concentration in water samples taken from reservoirs

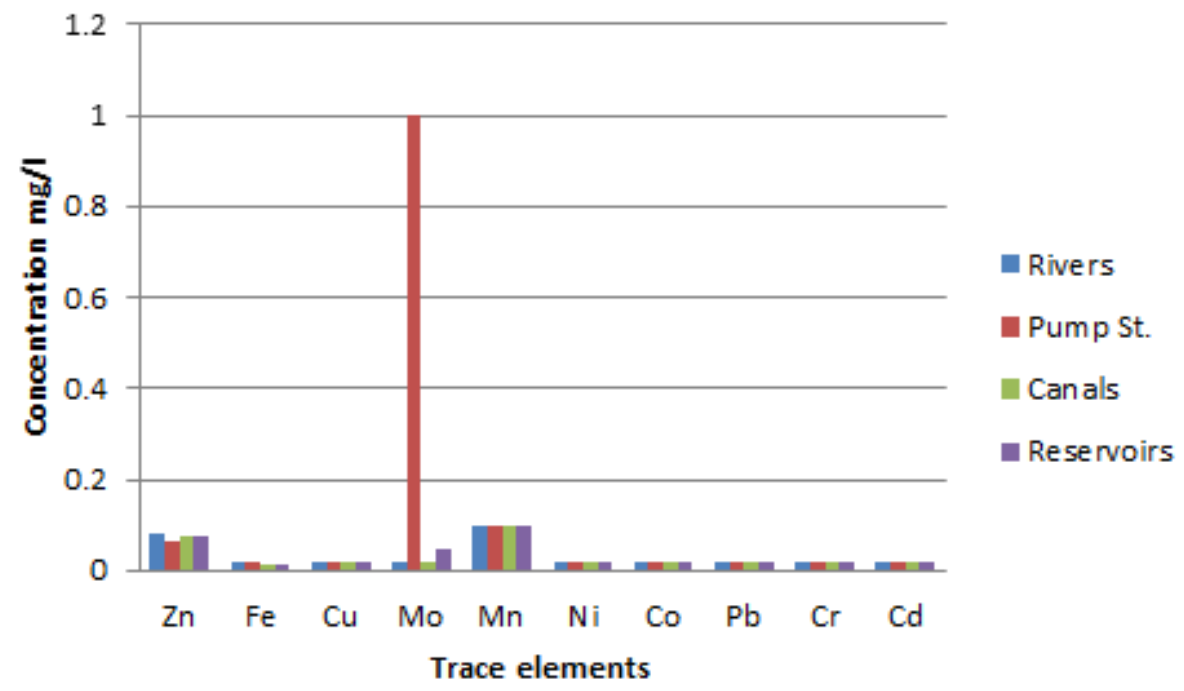

Figure 7. Trace elements concentration of water sources for irrigation

Regarding the dynamics of Fe content in relation to the irrigation water sources, we notice that a slightly lower level is present in canal and reservoir irrigation water (Figure 7).

As far as Mo concentration in irrigation water is concerned, we notice a relatively big difference between irrigation water from different sources. The highest levels are found in water samples obtained from pump stations and reservoirs, while its concentration in rivers and irrigation canals is presented in approximate values (Figure 7).

The results on the content of trace elements widely treated for all irrigation water sources enable us to carry out the assessment of possible toxicity by comparing them with the maximum permissible concentrations in irrigation water [11]; [8-9].

Table 1 also shows the maximum permissible levels for trace elements in irrigation water, which are $2.0 ; 5.0 ; 12: 20$; $12: 01 ; 12: 20 ; 12: 20 ; 12: 05 ; 5.0 ; 12: 10$; and $0.01 \mathrm{mg} / 1$ for $\mathrm{Zn}$, $\mathrm{Fe}, \mathrm{Cu}, \mathrm{Mo}, \mathrm{Mn}, \mathrm{Ni}, \mathrm{Co}, \mathrm{Pb}, \mathrm{Cr}$ and Cd respectively [5].
The comparison of the analyses results of all water samples with the recommended maximum concentrations indicate that copper, manganese, nickel, cobalt, lead and chromium are in normal concentrations; whereas the concentration of zinc $(0.06-0.09 \mathrm{mg} / \mathrm{l})$ and iron $(0.01-$ $0.03 \mathrm{mg} / \mathrm{l})$ are considered to be in insufficient levels.

Cadmium contents $(<0.02 \mathrm{mg} / \mathrm{l})$ were found to be in the recommended maximal concentrations. Although most of heavy metals do not pose a threat to humans through crop consumption, cadmium may be incorporated into plant tissue. Accumulation usually occurs in plant roots, but may also occur throughout the plant [18-19]. Cadmium should be kept within recommended levels due to its potential for accumulation in plants and soil in concentrations which can be dangerous for human beings.

The results of the study show that molybdenum is found in high concentrations especially in the water samples coming from pump stations and irrigation reservoirs. 
Molybdenum as all trace elements is found in primary minerals in rocks and soils frequently as isomorphic substitution (isomorphic substitution is the substitution of one element for another in clay minerals that may result in a net change in the electrical charge of the mineral), Molybdenum may also coprecipitate with secondary soil minerals, with iron and aluminum oxides [23]. These soil minerals serve as reservoirs for the trace elements, which are typically released at a slow rate into soil solutions and waters through a number of chemical weathering mechanisms.

Anthropogenic sources of Molybdenum include coal combustion residues. However, in dilute solutions, such as those found in soils or in most natural waters, the predominant form of soluble Mo is the molybdate anion, $\mathrm{MoO} /-[1]$.

An in depth analysis of the molybdenum contents found in the water samples shows that the values range in the interval $<0.02-5.9 \mathrm{mg} / \mathrm{l}$. By grouping the obtained values of molybdenum concentration according to the irrigation water sources in Kosovo, the following conclusions are drawn: Molybdenum concentrations measured in all the water samples taken from the rivers and irrigation canals were $<0.02 \mathrm{mg} / \mathrm{l}$. In all water samples collected from the pump stations the concentration of Mo ranges from $0.02-5.9 \mathrm{mg} / \mathrm{l}$, except one obtained at the Cagllavice sampling point, where the concentration was $<0.02 \mathrm{mg} / \mathrm{l}$. The maximal value in this interval, $5.9 \mathrm{mg} / \mathrm{l}$, was found in a pump station in Mihaliq-DO2. While in the water samples taken from the reservoirs at three sampling points, Mo concentrations were $<0.02 ; 0.1 ; 0.04 \mathrm{mg} / \mathrm{l}$ respectively.

The interval of values varying from $0.02-5.9 \mathrm{mg} / \mathrm{l}$ and indicating the concentration of molybdenum in irrigation waters is considered high and thus constitutes the main problem.

Other than the geological nature of the area itself, the relatively high concentrations of molybdenum may also be influenced by the coal combustion residues from the two Power Plants (Kosovo A and Kosovo B) of Kosovo Energy Corporation which are situated in the proximity of these water sources.

As regards the high concentration of Mo in the pump station in Mihaliq-DO2 we can add the fact that during the collection of the water samples, the pump station was not operating regularly.

In the future it is necessary to closely and continuously monitor the concentrations of molybdenum in the irrigation waters of this area, as well as identify the causes of the high molybdenum levels in these waters.

The ecological hazard of potentially toxic molybdenum is magnified when agricultural drainage waters are disposed into hydrologically closed basins and sinks and accumulate in the food chain.

The Mo contents $<0.02 \mathrm{mg} / 1$ were deemed to be in the recommended maximal concentrations, whereas the Mo contents $>0.02$ are considered to be slightly higher compared to the maximal concentrations recommended for irrigation water $(0.01 \mathrm{mg} / \mathrm{l})$. High levels of molybdenum can be toxic to fish and waterfowl, causing substantial harm to the ecosystem and, possibly, humans [20].

Molybdenum in very low concentrations has been found to be essential for the healthy growth of plants. The accumulation of molybdenum in plants is almost proportional to the amount of the element added to the soil. In nutrient and soil solution experiments $0.01 \mathrm{mg} / \mathrm{l}$ of molybdenum in solution will produce legumes containing around $5 \mathrm{mg} / \mathrm{kg}$ in the tissue [22].

The principal detrimental effect of molybdenum is the toxicity of these plants to cattle eating them. Effects of molybdenum toxicity are aggravated by conditions of copper deficiency and high sulfur intake. Toxic levels for molybdenum in forage crops are generally considered to be above 5 to $6 \mathrm{mg} / \mathrm{kg}$ for cattle and 10 to $11 \mathrm{mg} / \mathrm{kg}$ for sheep [22].

On the basis of possible animal toxicity from forage crops the maximum concentration in irrigation water is to be set at $0.01 \mathrm{mg} / 1$ [3]. This concentration is below the phytotoxic level but is recommended to protect animals from molybdosis because of excess molybdenum in forages. So, molybdenum is not toxic for plants in normal concentrations, but it could be toxic for livestock if forages are grown in lands with a high concentration of molybdenum [5].

Figure 7 shows that there are no significant differences in the content of trace elements among irrigation waters coming from rivers, reservoirs, pump stations or canals, except for Mo, which appears mostly in the pumping stations and reservoirs compared to irrigation waters deriving from rivers and canals.

The fact that the levels of some heavy metals in water were much lower than prescribed values does not translate into total safety of the water because the trace amounts detected for some elements is still worthy of consideration and further monitoring to ensure that levels do not exceed what has been detected.

\section{Conclusions}

The presence of trace elements is evident in all the water samples from the irrigation sources in the agricultural areas in Kosovo. However, their values vary according to the type of element and to the analyzed sample. The $\mathrm{pH}$ values measured are within permissible limits for irrigation water.

The comparison of the analyses results of all water samples with the recommended maximum concentrations indicates that copper, manganese, nickel, cobalt, lead and chromium are in normal concentrations; whereas the concentration of zinc and iron are considered to be in insufficient levels.

Cadmium contents were found to be in the recommended maximal concentrations. Cadmium should be kept within recommended levels due to its potential for accumulation in plants and soil in concentrations which can be harmful for human beings. 
By classifying the obtained values of molybdenum concentration according to the irrigation water sources in Kosovo, the following conclusions are drawn: Molybdenum concentrations measured in all the water samples taken from rivers and irrigation canals were $<0.02 \mathrm{mg} / \mathrm{l}$. In all water samples collected from pump stations and reservoirs the concentration of Mo ranges from 0.02-5.9 mg/l. The maximal value in this interval, $5.9 \mathrm{mg} / \mathrm{l}$, was found in a pump station in Mihaliq-DO2.

The interval of values varying from $0.02-5.9 \mathrm{mg} / \mathrm{l}$ and indicating the concentration of molybdenum in irrigation waters is considered high and thus constitutes the main problem.

Other than the geological nature of the area itself, the relatively high concentrations of molybdenum may also be influenced by the presence of coal combustion residual from the two Power Plants (Kosovo A and Kosovo B) of Kosovo Energy Corporation which are situated in the proximity of these water sources.

As regards the high concentration of Mo in the pump station in Mihaliq-DO2 we can add the fact that during the collection of the water samples, the pump station was not operating regularly.

In the future it is necessary to closely and continuously monitor the concentrations of molybdenum in the irrigation waters of this area, as well as identify the causes of the high molybdenum levels in these waters.

The Mo contents $<0.02 \mathrm{mg} / \mathrm{l}$ were deemed to be in the recommended maximal concentrations, whereas the Mo contents $>0.02$ are considered to be slightly higher compared to the maximal concentrations recommended for irrigation water. High levels of molybdenum can be toxic to fish and waterfowl, causing substantial harm to the ecosystem and, possibly, humans. Molybdenum is not toxic for plants in normal concentrations, but it could be toxic for livestock if forages are grown in lands with a high concentration of molybdenum.

There are no significant differences in the content of trace elements among irrigation waters coming from rivers, reservoirs, pump stations or canals, except for Mo, which appears mostly in the pumping stations and reservoirs compared to irrigation waters deriving from rivers and canals.

Therefore, these sources can be used for irrigation purposes without posing a threat to the soil and plants. Further monitoring in order to ensure that the detected levels are not exceeded is essential and should be on a regular basis and different spatial and temporal settings because they are key factors with which concentrations differ.

\section{REFERENCES}

[1] Adriano, D.C. Trace Elements in the Terrestrial Environment. Springer, New York, 1986, pp. 329-361
[2] Abazi U., Laze P., Stasa J. Contents of heavy metals in surface water and sediments in Mati and Gjanica rivers in Albania. Journal of Food, Agriculture and Environment. Vol. 11(3\&4), July-October 2013: 2227 - 2231, 2013.

[3] Albasel, N. and Pratt, P. F. Guidelines for Molybdenum in Irrigation Waters. Journal of Environmental Quality 1989 $18: 259-264$

[4] Alloway, B. J. Heavy Metals in Soils. Blackie Academic and Professional: London. Pp. 7-39, 1995.

[5] Ayers, R. S. \& Westcott D. V. Water quality for agriculture. FAO Irrigation \& Drainage, Paper nr. 29. FAO, Roma.174 p, 1985.

[6] Bradl H, editor. Heavy Metals in the Environment: Origin, Interaction and Remediation Volume 6.London: Academic Press, 2002.

[7] Chary N.S., Kamala C.T., Raj D.S.S. Assessing risk of heavy metals from consuming food grown on sewage irrigated soils and food chain transfer. Ecotoxicol. Environ. Saf., 69 (3) pp.513-524, 2008.

[8] Council Directive 75/440/EEC of 16 June 1975 concerning the quality required of surface water intended for the abstraction of drinking water in the Member States

[9] DIRECTIVE 2008/105/EC OF THE EUROPEAN PARLIAMENT AND OF THE COUNCIL of 16 December 2008 on environmental quality standards in the field of water policy, amending and subsequently repealing Council Directives 82/176/EEC, 83/513/EEC, 84/156/EEC, 84/491/EEC, 86/280/EEC and amending Directive 2000/60/EC of the European Parliament and of the Council

[10] European Commission IN-DEPTH REPORT Soil Contamination: Impacts on Human Health Environment. Science for Environment Policy, September 2013 Issue 5, 2013.

[11] FAO. Water Quality for Agriculture (Table 21. Recommended maximum Concentrations of trace elements in irrigation water). Paper No. 29 (Rev. 1) UNESCO, Publication, Rome. 1985.

[12] Fergusson JE, editor. The Heavy Elements: Chemistry, Environmental Impact and Health Effects. Oxford: Pergamon Press; Pp. 377-405, 1990.

[13] Gonzalez, A. E. M. T. Rodriguez, J. C.J. Sanchez, A. J. F. Espinosa, F. J. B. Rosa and F.J.R. Barragan Assessment of metals in sediments in a tributary of Guadalquivir River (Spain). Water, Air and Soil Pollution. 121(1-4): 11-29, 2000.

[14] He ZL,Yang XE, Stoffella PJ. Trace elements in agroecosystems and impacts on the environment. J Trace Elem Med Biol.; 19(2-3):125-140, 2005.

[15] Kabata- Pendia A 3rd, editor. Trace Elements in Soils and Plants. Boca Raton, FL: CRC Press; 2001.

[16] Klaus-J Appenorth, Definition of "Heavy Metals" and Their Role in Biological Systems. In book: Soil Heavy Metals, pp.19-29, 2010. Friedrich Schiller University Jena.

[17] Landon, J. R. (ed) Booker Tropical Soil Manual, John Wiley and Sons Inc.; New York. 1991. 
[18] Mendez G., A. Flores R., S. Palacios M Disponibilidad de Cd, $\mathrm{Fe}, \mathrm{Mn}$ y $\mathrm{Pb}$ ensuelos agricolas de Tecamachalco, Edo. De Puebla. Pp. 60. In: Memorias del XXVIII, Congreso Nacional de la Ciencia del Suelo, Villahermosa, Tabasco. Rodrigues D. 1997.

[19] Mendez G., A. Salas C (1995) Contaminación de los suelos del Ejido Flores Magon, municipio de Atlixopor Fe, Mn, Zn y Pbpor el uso de aguas del rioAtoyac, pp. 34. In memorias, XXVI, Congreso Nacional de la Ciencia del Suelo. Cd. Victoria, Tamps,

[20] National Research Council. 1993. Salts and Trace Elements. Soil and Water Quality: An Agenda for Agriculture. Washington, DC: The National Academies Press. https://doi.org/10.17226/2132.

[21] Raymond. W Miler., Roy. L Donhaue. Soil in our environment (5 th edition), p. $480-486,1995$.

[22] Rijtema, P, E. WATER QUALITY CRITERIA FOR AGRICU LTU RAL WATER USE. Instituut voor Cultuurtechniek en Waterhuishouding Wageningen, NOTA 856 november 1975.

[23] Sposito, G. The Chemistry of Soils. Oxford University Press, 1989 - 277 pages.
[24] Stasinos, S. \& Zabetakis, I. The uptake of nickel and chromium from irrigation water by potatoes, carrots and onions. Source: 11 July 2013 Issue 336 Ecotoxicology and Environmental Safety, 91.122- 128, 2013. DOI 10.1016/j.ecoenv.2013.01

[25] Stephens, S. R. B. J. Alloway, J. E. Carter and A. Parker. Towards the characterisation of heavy metals in dredged canal sediments and an appreciation of availability. Environ. Pollution. 113(3): 395- 401. (2001)

[26] Tamariz F, Contaminación de los suelos agricolaspor metals pesados en el Municipiode Atlixo, Puebla Tesis de Mestria en Edafologia. Faculdad de Ciencias, Universidad Nacional Autonoma de México, México. 1996.

[27] Terrance Hettipathirana. Determination of metals in industrial waste waters by microwave plasma atomic emission spectrometry (MP-AES 4100). Application note Environmental, Agilent Technologies Melbourne, Australia. 2011.

[28] Toxic chemicals hazard of Irrigation water. http://www.lenntech.com/applications/irrigation/toxic/toxic-i ons-hazard-of- irrigation-water.htm (Accessed in 2012.06.19). 